\title{
Macro- and Micro-morphological, Anatomical, Cytological and Phytochemical Properties of Tridax procumbens Linn. (Asteraceae)
}

\author{
*WAHUA, C; PEPPLE, I I \\ Department of Plant Science and Biotechnology, University of Port Harcourt, Choba, Port Harcourt, Nigeria \\ *Corresponding Author Email: chika.wahua@uniport.edu.com; Tel: +2348064043448
}

\begin{abstract}
This study examined the macro- and micro-morphological, Anatomical, Cytological and Phytochemical Properties of Tridax procumbens L. in the family Asteraceae. Observations of plant parts aided by measurements were done and these were sectioned following Wahua's method; root tips squashed with FLP Orcein and qualitative phytochemical analyses were carried out. The slides were viewed using the light compound microscope and photomicrographs were taken after careful examination from good preparations. Macromorphological studies showed the plant grows up to $40 \mathrm{~cm}$ or more in height. Foliar features revealed opposite, pinnate, oblong to ovate with coarsely serrated margin and acute apex, $4 \pm 1.5 \mathrm{~cm}$ long and $2 \pm 1 \mathrm{~cm}$ wide with petiole up to $1.5 \pm 0.5 \mathrm{~cm}$ in length. The floral structure show cased diameter of each flower head as $1.0 \pm 0.4 \mathrm{~cm}$ while the peduncle is elongated and up to $10 \pm 5 \mathrm{~cm}$ in length; the petal is $0.7 \pm 0.2 \mathrm{~cm}$ in length alongside tubular sepals up to $0.9 \pm 0.3 \mathrm{~cm}$ in length. The stamen is $0.9 \pm 0.2 \mathrm{~cm}$ in length while the carpel is $1.0 \pm 0.1 \mathrm{~cm}$. Presence of anomocytic stomata which is amphistomatic. Anatomical sections on the mid-ribs, petiole, internodes, nodes and roots revealed peculiar internal features. Mitotic chromosome is $2 n=36$. Phytochemical studies revealed the presence of saponins, alkaloids, flavonoids, tannins, steroids, cardiac glycosides, phenols. The information generated from this study would further aid in the delimitation of the species.
\end{abstract}

\section{DOI: $\underline{\text { https://dx.doi.org/10.4314/jasem.v24i4.9 }}$}

Copyright: Copyright $(\mathrm{C} 2020$ Wahua and Pepple. This is an open access article distributed under the Creative Commons Attribution License (CCL), which permits unrestricted use, distribution, and reproduction in any medium, provided the original work is properly cited.

Dates: Received: 11 February 2020; Revised: 19 March 2020; Accepted: 29 March 2020

Keywords: Tridax procumbens, Morphology, anatomy, cytology, palynology, phytochemistry

The Genus Tridax consists of species of flowering plants belonging to family Asteraceae made of about 30 species, native to tropical America and introduced to subtropical and mild temperate regions worldwide. Tridax species are more of noxious weeds in the United States and have pest status. Some of the medicinally important species of the genus Tridax are: T. angustifolia, T. serboana, T. bicolor, T. accedens, T. dubia, T. erecta and T. rosea. Tridax procumbens L. commonly known as coat buttons or Tridax daisy. The plant is native of tropical America and naturalized in tropical Asia, Africa, Australia, India and Nigeria. It is a wild herb distributed throughout India. It is also found along road sides, waste grounds, dikes, river banks, meadows and dunes (Dassanayake, 1980). The juice extracted from the leaves is directly applied on wounds. Its leaf extracts were used for infectious skin diseases in folk medicines. It is used for staunching bleeding and treatment of diarrhea; for backache (Burkhill, 1985) and bronchial catarrh (Ambasta, 1886). Phytochemical screening for saponins has frothing tests as evidence it presence (Wall et al., 1952). Tridax procumbens L. consisted of glandular and non-glandular type of trichomes. (Metcalfe and Chalk, 1950; Stace, 1940). The objective investigates the following: macro- and micro-morphological features, anatomical, cytological and phytochemical analyses of Tridax procumbens $\mathrm{L}$.

\section{MATERIALS AND METHODS}

Morphological Studies: Observations of the morphological characters (vegetative and floral) were made and a meter rule was employed to aid in the measurements. The seeds were obtained from Rumuokoro market in Port Harcourt while the plant parts were collected from University of Port Harcourt farm.

Anatomical Studies: Fresh plant parts (stem, midrib, petiole, node and roots) collected were fixed in FAA solution (in the ratio of $1: 1: 18$ ) for 48 hours, (Johansen, 1940) with some modifications, and later subjected to free hand sectioning using 5 blades as described by (Wahua et al., 2013). These were dehydrated in ethanol solution of $30 \%, 50 \%, 70 \%$ and absolute for 5 minutes in each and further passed through different series of alcohol and chloroform $(3: 1,1: 1$ and $1: 3) \mathrm{v} / \mathrm{v}$ for 10 minutes in each and returned back following same time intervals to $50 \%$ alcohol. Good sections were selected, stained with $1 \%$ Alcian blue, rinsed and counter stained with $1 \%$ Safranin 0 for 2 minutes. Mounted on glass slides with 
a drop of glycerol and viewed under the microscope. Microphotographs were taken.

Cytological Studies: The seeds were plated in petridishes with wetted Whatman paper and allowed to germinate. The roots were harvested in the morning: 8a.m, 9a.m., 10a.m., 11 a.m. and 12 noon respectively and kept in 8 hydroxylquinoline for 3hours in each before fixing in Carnoy's fluid for 24hours (Okoli, 1983). The roots were removed and hydrolyzed in $8 \%$ $\mathrm{HCl}$ kept in water bath at $60^{\circ} \mathrm{C}$ for 5 minutes. Thereafter, roots were placed in $70 \%$ ethanol for 10 minutes to neutralize the acid. Then $2 \mathrm{~mm}$ root tip was excised and placed on a glass slide with a drop of FLP Orcein covered with a cover slip and squashed using the flat end of a biro. Air bubbles and excess stain were removed using filter paper. Photomicrographs were taken from good preparations.

Phytochemical Study: Leaves of Tridax procumbens Linn studied were sun dried for 72 hours (3 days) and weighed. Fifty grams $(50 \mathrm{~g})$ of the dried leaves were macerated in $96 \%$ ethanol using a pestle and a mortar. The extract was thereafter filtered and evaporated to dryness (constant weight) using a rotary evaporator set at $45^{\circ} \mathrm{C}$. Residue yields were noted and a portion was used for the phytochemical screening.

Phytochemical screening for saponin: Frothing tests was done following the method described by Wall et al. (1952). The ability of saponins to produce frothing in aqueous solution and to haemolyse red blood cells were used as screening test for these compounds. $0.5 \mathrm{~g}$ of the plant extract was shaken with water in a test tube. Frothing which persisted on warming was taken as preliminary evidence for the presence of saponins.

The disc was then washed in ether, dried and placed on a 7 percent blood nutrient agar. Complete haemolysis of red blood cells around the disc after 6 hours was taken as further evidence for the presence of saponins.

Test for alkaloids: $0.5 \mathrm{~g}$ of the plant extract was stirred with $5 \mathrm{ml}$ of 1 percent aqueous hydrochloric acid on a steam bath; $1 \mathrm{ml}$ of the filtrate was treated with a few drops of Mayer's reagent and a second $1 \mathrm{ml}$ portion was treated similarly with Dragendorff's reagent. Turbidity or precipitation with either of these reagents was taken as preliminary evidence for the presence of alkaloids in the extract being evaluated (Harborne, 1973; Trease and Evans, 1989). A modified form of the tin-layer chromatography (TLC) method as described by Farnsworth and Euer (1962) was used. One gram $(1 \mathrm{~g})$ of the extract was treated with 40 percent calcium hydroxide solution until the extract was distinctly alkaline to litmus paper, and then extracted twice with $10 \mathrm{ml}$ portions of chloroform. The extracts were combined and concentrated in vacuo to $5 \mathrm{ml}$. The chloroform extract was then spotted on thinlayer plates. Four different solvent systems were used to develop each plant extract. The presence of alkaloids in the developed chromatograms was detected by spraying the chromatograms with freshly prepared Dragendorff's spray reagent. A positive reaction on the chromatograms (indicated by an orange or darker colored spot against a pale yellow background) was confirmatory evidence that the plant extract contained alkaloid.

Test for tannins: Five grams $(5 \mathrm{~g})$ of each portion of plant extract was stirred with $10 \mathrm{ml}$ of distilled water, filtered and 5\% ferric chloride reagent added to the filtrate. A blue-black, green, or blue-green precipitate was taken as evidence for the presence of tannins (Shoppee, 1964).

Test for anthraquinones: Borntrager's test was used. Five grams $(5 \mathrm{~g})$ of each plant extract was shaken with $10 \mathrm{ml}$ benzene, filtered and $5 \mathrm{ml}$ of 10 per cent ammonia solution added to the filtrate. The mixture was shaken and the presence of a pink, red, or violet.

\section{RESULTS AND DISCUSSION}

Morphology: Tridax procumbens L. is a hirsute, perennial herb with very dense hairy structure. The leaves are simple, ovate to lanceolate in shape, decussate with cuneate base, acute apex, serrated to coarsely dentate margins and ex-stipulate opposite phyllotaxi. It grows up to $40 \mathrm{~cm}$ or more in height. (Plates 1, 2 and 3).

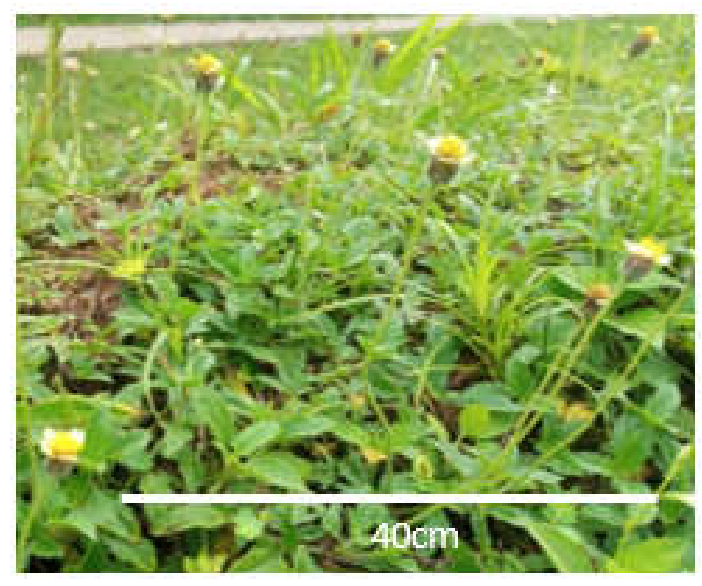

Plate 1: Tridax procumbens $\mathrm{L}$.

The floral structure show cased diameter of each flower head as $1.0 \pm 0.4 \mathrm{~cm}$ while the peduncle is elongated and up to $10 \pm 5 \mathrm{~cm}$ in length; the petal is $0.7 \pm 0.2 \mathrm{~cm}$ in length alongside tubular sepals up to 
$0.9 \pm 0.3 \mathrm{~cm}$ in length. The stamen is $0.9 \pm 0.2 \mathrm{~cm}$ in length while the carpel is $1.0 \pm 0.1 \mathrm{~cm}$. The Bisexual flower head or inflorrescence is actinormorphic with numerous disc florets per head, tubular-campanulate structure and axillary or terminal in position. Ray floret are zygomorphic and ligulate. See (Plates 3A and B). The leaves are $4 \pm 1.5 \mathrm{~cm}$ in length and $2 \pm 1 \mathrm{~cm}$ wide with petiole up to $1.5 \pm 0.5 \mathrm{~cm}$ in length. See (Table 1 and 2).
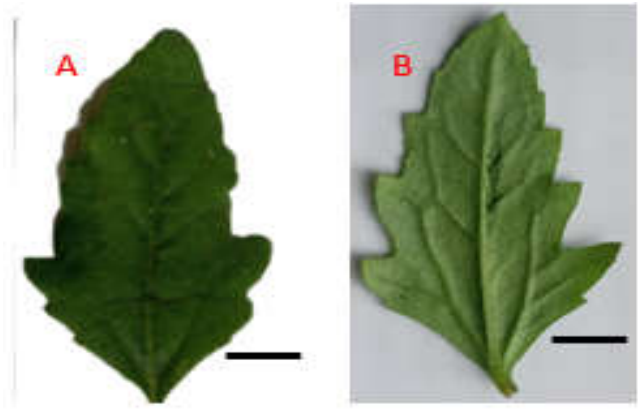

Plate 2A: T. procumbens Abaxial Foliar Surface; Plate 2B: $T$. procumbens Adaxial Foliar Surface
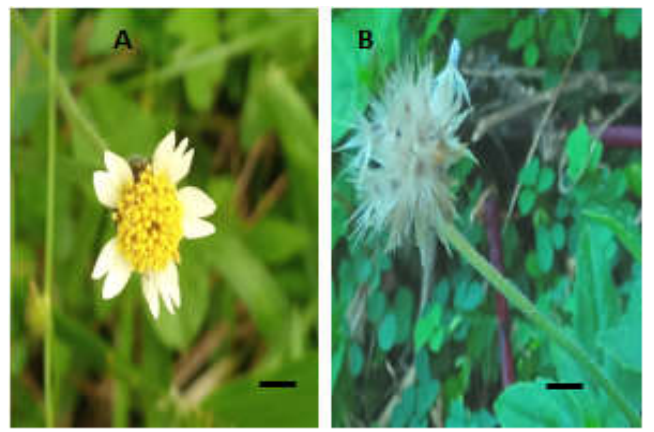

Plate 3A: Tridax procumbens L. Inflorescence of flower head; Plate 3B: Dried Flower head Dispersed by wind.

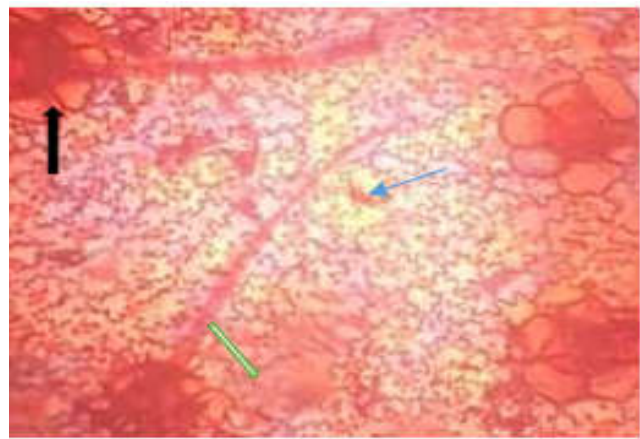

Plate 4: T. procumbens Abaxial foliar epidermis revealed the following: Black arrow indicates the trichome base, while white arrow shows the linear multiseriate trichome, tapering to a tip and blue arrow showcased anomocytic stoma. The guard cells and the rest of epidermal cells have same resemblance.

Micro-morphology: Tridax procumbens is amphistomatic with anomocytic type of stomata, more abundant on abaxial surface. Linear or unbranched multiseriate trichomes are observed on both surfaces and visible to the naked eyes.

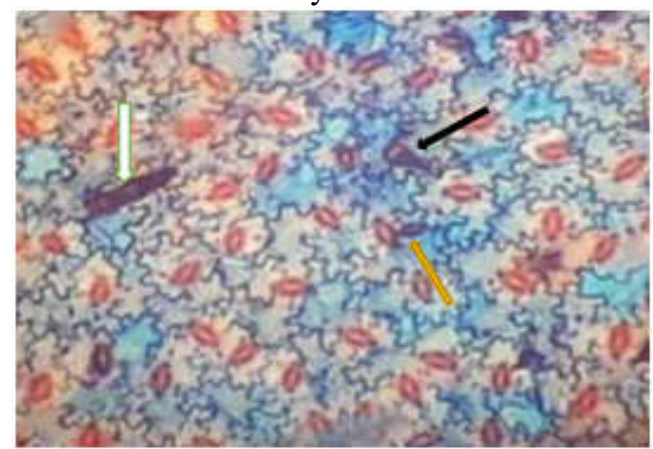

Plate 5: T. procumbens adaxial foliar epidermis. White arrow revealed trichome, black arrow shows biseriate glandular trichome while brown arrow show cased contiguous cells.

Morphological characteristics of Tridax procumbens L. revealed the foliar features as simple and decussate with opposite phyllotaxy, ovate and margins serrate to coarsely dentate, tips are acute, bases are cuneate and inflorescences terminal. These are in confirmation with the works of Dassanayake (1980). Amphistomatic condition observed. Anomocytic stomata were more abundant on the lower surface (Metcalfe and Chalk, 1950). Uniseriate glandular trichomes were sparingly dispersed in both adaxial and abaxial foliar surfaces. See (Plates 4 and 5).

Anatomy: The internal organization of cells from the epidermis, hypodermis, general cortex, endodermis, pericycle, open vascular system and pith revealed similar cells and tissues arrangement for stem, mid-rib, petiole and root sections. Collenchyma dominates the hypodermis whereas the general cortex and pith is made of parenchyma. See Table 3.

Anatomical Properties The presence of rib-bundle wing having vascular ribs $(\mathrm{Rb})$ is unique to mid rib Tridax procumbens.(Plate 6).

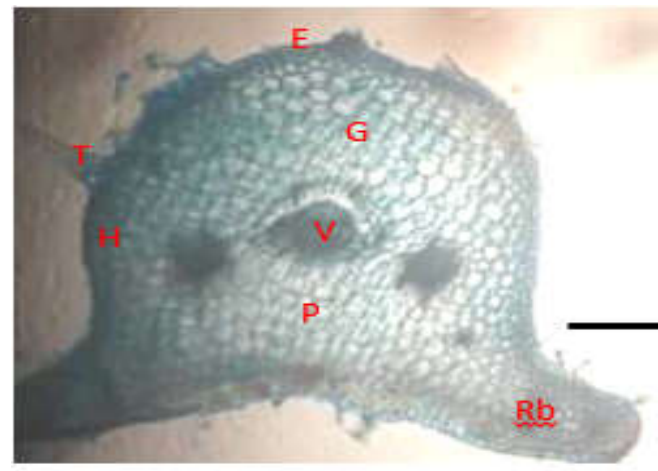

Plate 6: midrib anatomy of $T$. procumbens (T.S.). Scale Bar represents $2 \mathrm{~mm}$. T represents Trichome, E represents Epidermis, G is General cortex, $\mathrm{H}$ stands for hypodermis, $\mathrm{V}$ for vascular bundle, $\mathrm{P}$ is Pith, $\mathrm{Rb}$ represents Rib bundle wing. 
Table 1: Morphological Characteristics of Tridax procumbens Linn.

\begin{tabular}{|c|c|c|c|c|c|c|c|c|c|c|}
\hline \multirow{2}{*}{$\begin{array}{l}\text { Taxa } \\
\text { Tridax } \\
\text { procumbens }\end{array}$} & & \multirow{2}{*}{\multicolumn{2}{|c|}{$\begin{array}{l}\text { Stem } \\
\text { Pilose (densely } \\
\text { hairy) and } \\
\text { hirsute } \\
\text { perennial herb. }\end{array}$}} & \multirow{2}{*}{\multicolumn{2}{|c|}{$\begin{array}{l}\text { Leaf } \\
\text { Simple, opposite, ovate to } \\
\text { lanceolate and decussate } \\
\text { with cuneate base, acute } \\
\text { apex and serrated to } \\
\text { coarsely dentate margin. }\end{array}$}} & \multicolumn{3}{|c|}{ Flower/Inflorescence } & \multirow{2}{*}{\multicolumn{2}{|c|}{$\begin{array}{l}\text { Plant Height } \\
\text { Herbaceous } \\
\text { perennial with } \\
\text { spreading basal } \\
\text { portion and grows } \\
\text { up to } 40 \mathrm{~cm} \text { or more. }\end{array}$}} \\
\hline & Linn. & & & & & \multicolumn{3}{|c|}{$\begin{array}{l}\text { Pentamerous, bisexual and } \\
\text { actinomorphic solitary head with } \\
\text { yellowish numerous disc floret per } \\
\text { head having ubular-campanulate } \\
\text { involucres. Axillary or terminal. }\end{array}$} & & \\
\hline $\begin{array}{l}\text { Plant } \\
\text { Height } \\
(\mathrm{cm}) \\
40 \text { or more } \\
\end{array}$ & 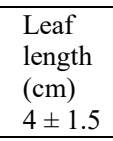 & $\begin{array}{l}\text { Leaf } \\
\text { width } \\
(\mathrm{cm}) \\
2 \pm 1 \\
\end{array}$ & 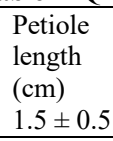 & $\begin{array}{l}\text { Flower head } \\
\begin{array}{l}\text { Diameter } \\
(\mathrm{cm})\end{array} \\
1.0 \pm 0.4\end{array}$ & $\begin{array}{l}\text { Inflor } \\
\text { Pedun } \\
\text { (cm) } \\
10 \pm\end{array}$ & $\begin{array}{l}\text { scence } \\
\text { le length }\end{array}$ & $\begin{array}{l}\begin{array}{l}\text { Petal } \\
\text { length } \\
(\mathrm{cm})\end{array} \\
0.7 \pm 0.2 \\
\end{array}$ & $\begin{array}{l}\text { Sepal } \\
\text { Length } \\
\text { (cm) } \\
0.9 \pm 0.3 \\
\end{array}$ & $\begin{array}{l}\begin{array}{l}\text { Stamens } \\
\text { Length } \\
(\mathrm{cm})\end{array} \\
0.9 \pm 0.2 \\
\end{array}$ & $\begin{array}{l}\text { Carpel } \\
\text { Length } \\
(\mathrm{cm}) \\
1.0 \pm 0.1 \\
\end{array}$ \\
\hline & Epidermis & Hypo & ermis & General cortex & Endo & dermis & Pericyle & $\begin{array}{l}\text { Vascular } \\
\text { Bundle }\end{array}$ & Pith & \\
\hline Petiole & $\begin{array}{l}1 \text { roll o } \\
\text { cells }\end{array}$ & $\begin{array}{l}2 \text { roll } \\
\text { collen }\end{array}$ & $\begin{array}{l}\text { of cells } \\
\text { hyma }\end{array}$ & $\begin{array}{l}4 \text { to } 5 \text { rolls of } \\
\text { cells } \\
\text { Parenchyma }\end{array}$ & Not & served & $\begin{array}{l}\text { Not } \\
\text { observed }\end{array}$ & $\begin{array}{l}\text { Open } \\
\text { type }\end{array}$ & $\begin{array}{l}3 \text { to } 4 \mathrm{ro} \\
\text { parenchy }\end{array}$ & $\begin{array}{l}\text { s of cells } \\
\text { na }\end{array}$ \\
\hline Mid-rib & $\begin{array}{l}1 \text { roll o } \\
\text { cells }\end{array}$ & $\begin{array}{l}2 \text { roll } \\
\text { collen }\end{array}$ & $\begin{array}{l}\text { of cells } \\
\text { hyma }\end{array}$ & $\begin{array}{l}4 \text { to } 5 \text { rolls of } \\
\text { cells } \\
\text { parenchyma }\end{array}$ & Not & bserved & $\begin{array}{l}\text { Not } \\
\text { observed }\end{array}$ & $\begin{array}{l}\text { Open } \\
\text { type }\end{array}$ & $\begin{array}{l}6 \text { to } 7 \\
\text { paren }\end{array}$ & $\begin{array}{l}\text { s of cells } \\
\text { na }\end{array}$ \\
\hline Stem & $\begin{array}{l}1 \text { roll o } \\
\text { cells }\end{array}$ & $\begin{array}{l}2 \text { t0 } 3 \\
\text { ( colle }\end{array}$ & $\begin{array}{l}\text { cell thick } \\
\text { chyma) }\end{array}$ & $\begin{array}{l}4 \text { t0 } 5 \text { cell thick } \\
\text { (parenchyma) }\end{array}$ & Not & bserved & $\begin{array}{l}\text { Not } \\
\text { observed }\end{array}$ & $\begin{array}{l}\text { Open } \\
\text { type }\end{array}$ & $\begin{array}{l}15 \text { to } 2 \\
\text { cells aci } \\
\text { of paren }\end{array}$ & $\begin{array}{l}\text { rolls of } \\
\text { ss, made } \\
\text { nyma. }\end{array}$ \\
\hline Root & $\begin{array}{l}1 \text { roll o } \\
\text { cells }\end{array}$ & 2 rolls & of cells & $\begin{array}{l}3 \text { rolls of cells } \\
\text { (parenchyma) }\end{array}$ & $\begin{array}{l}1 \mathrm{rol} \\
\text { shap }\end{array}$ & $\begin{array}{l}\text { of barrel } \\
\text { d cells }\end{array}$ & Observed & $\begin{array}{l}\text { Open } \\
\text { type }\end{array}$ & $\begin{array}{l}4 \text { to } 5 \mathrm{rc} \\
\text { across } \mathrm{p}\end{array}$ & s of cells \\
\hline
\end{tabular}

The petiole has vascular arcs. The hypodermal layer is made of 2 to 3 rolls of collenchyma while the general cortex is dominated by parenchyma. See (Plate 7).

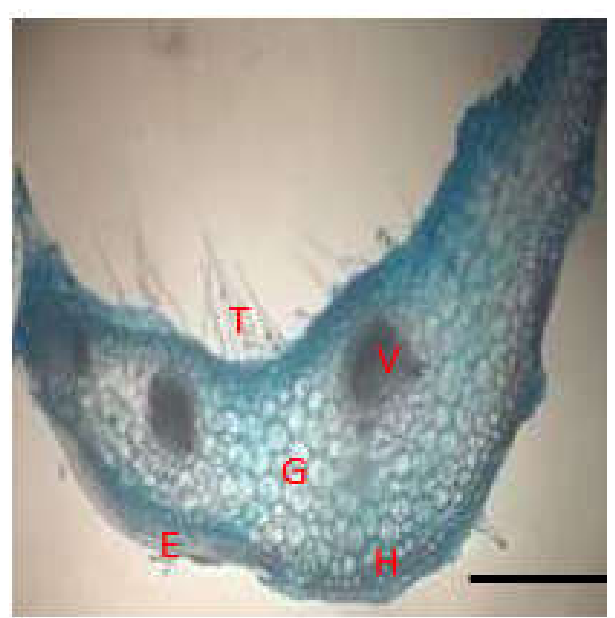

Plate 7: Petiole (T.S.). T represents Trichome, E represents Epidermis, $\mathrm{G}$ is General cortex, $\mathrm{H}$ stands for hypodermis, $\mathrm{V}$ for vascular bundle, $\mathrm{Ph}$ represents Phloem.

The stem has clearly marked hypodermis made of 4 to 5 rolls of collenchyma while the parenchyma of the general cortex has 5 to 6 rolls of cells. The interfascicular cambium is prominently observed. The pith is occupied by parenchyma. Plate 8. The root anatomy of $T$. procumbens revealed 2 to 3 rolls of hypodermal cells, below which are 4 to 5 rolls of parenchyma in the general cortex, the endodermal layer is made of a single layer of barrel shaped cells and the pericyclic zone has several rolls of cells, the xylary rays and vessel elements are prominently visible. Plate 9.

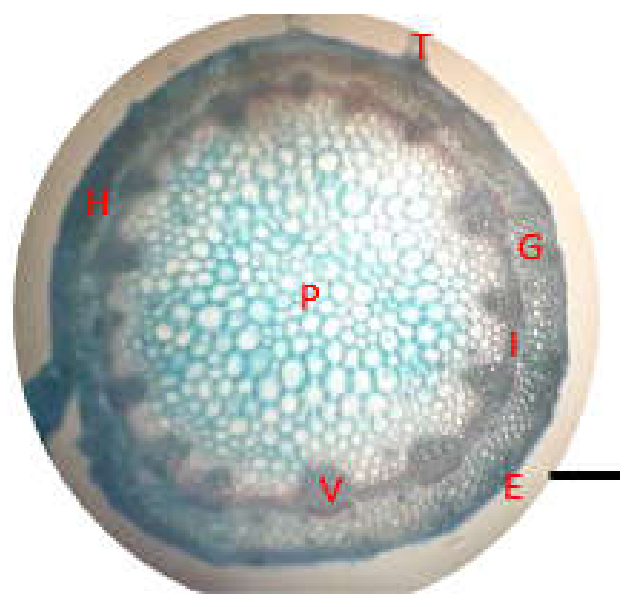

Plate 8: T. procumbens Stem anatomy (T.S.). $\mathrm{H}$ is hypodermis, $\mathrm{G}$ is general cortex, I represents Interfascicular cambium, E is epidermis, $\mathrm{V}$ stands for vascular bundle and $\mathrm{P}$ is pith.

The anatomical study revealed the similarities in cells and tissue pattern which exist among the leaf, petiole, node, root, and stem of the species. In Tridax procumbens L., collenchyma occupied the hypodermal region while parenchyma is found in the ground tissues and vascular bundles are bicollateral. Cytology: Mitotic chromosome numbers at metaphase revealed a diploid which is $2 n=36$. (Plates. $10 \mathrm{~A}$ and 10B). 


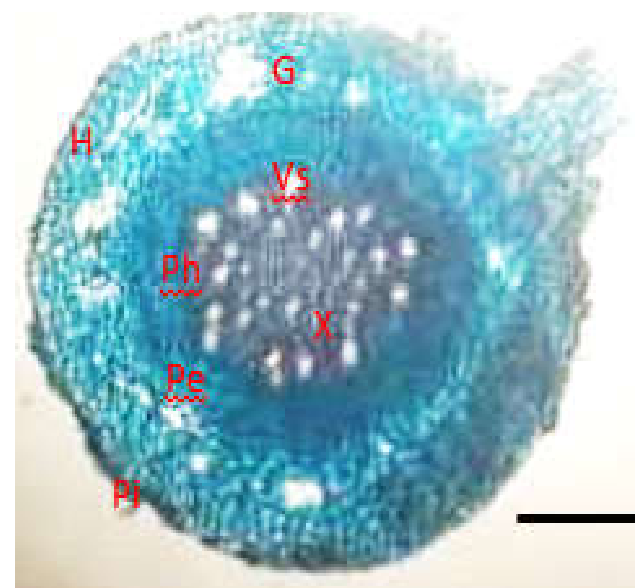

Plate 9: T. procumbens root anatomy. Pi represents piliferous layer, $\mathrm{H}$ is hypodermis, $\mathrm{G}$ is general cortex, $\mathrm{Pe}$ is pericycle, $\mathrm{Ph}$ - phloem, vs is vessel element, $\mathrm{x}$ - xylary rays.

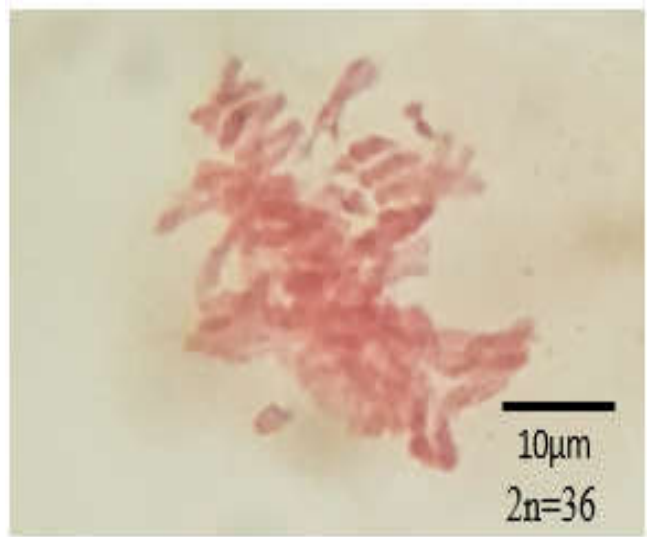

Plate 10A: Tridax procumbens mitotic chromosmes at metaphase.

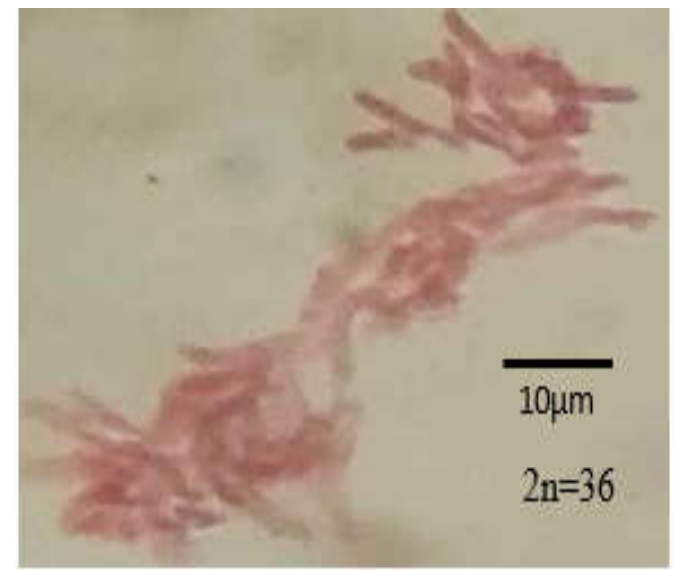

Plate 10B: T. procumbens mitotic chromosomes more on a lineal fashion

Cytological investigations carried out revealed a diploid number of $2 \mathrm{n}=36$ chromosomes present in Tridax procumbens Phytochemistry: The phytochemical studies revealed aglycone glycoside as the most abundant secondary metabolites present in Tridax procumbens $\mathrm{L}$. Table 4.
Table 4: Phytochemical composition of Tridax procumbent $\mathrm{L}$

\begin{tabular}{llll}
\hline Phytochemical & Methanol & Ethanol & Aqueous \\
\hline Saponin & + & ++ & +++ \\
Alkaloid & ++ & + & - \\
Flavonoid & ++ & + & +++ \\
Tannin & + & - & - \\
Steroid & +++ & ++ & - \\
Terpenoids & ++ & + & - \\
Cardiac Glycoside & ++ & ++ & + \\
Aglycone Glycoside & +++ & +++ & +++ \\
Steroidal Glycoside & +++ & +++ & +++ \\
Phenol & - & - & + \\
\hline Keys: +++ signifies abundantly present; ++ signifies highly \\
\multicolumn{2}{c}{ present; + signifies present; - signifies absent }
\end{tabular}

Phytochemical analysis of Tridax procumbens L. revealed the presence of diverse phytochemicals such as saponins, flavonoids, terpernoids, cardiac glycosides, alkaloids, aglycone glycosides, steroids, tannins, phenols among others. T. procunbens is highly rich in aglycone glycosides.

Conclusion: Tridax procumbens L. though known as herbaceous perennial weed, has lots of phytotherapeutic properties. The aglycone glycosides, steroids and steroidal glycosides are more in concentration than the other secondary metabolites studied.

\section{REFERENCES}

Ambasta, SSP (1986). The Useful Plants of India. New Delhi, India: Publications and Information Directorate, Council of Scientific and Industrial Research.

Burkhill, HM (1985). The Useful Plants of West Tropical Africa. Vol. I. Families A-D. Kew, UK: Royal Botanic Gardens.

Dassanayake, MDA (1980). Revised Handbook to the Flora of Ceylon. Vol. I. Amerind Publishing Co. Pvt. Ltd., New Delhi.

Farnsworth, NR; Euer, K L (1962). An Alkaloid screening procedure utilizing thin-layer chromatograph. Lioydia, 25-186.

Harborne, JB (1973). Phytochemical Methods: A Guide to Modern Techniques of Plant Analysis. Chapman \& Hall, London. 279 pp.

Johansen H (1940). Plants Micro technique. McGrawHill, New York. 532 pp.

Metcalfe, CR; Chalk, L (1950). Anatomy of Dicotyledons. Vol. II. Oxford University Press Amen House, London. 
Okoli, BE (1983). Hybridization, polyploidy and apomixes in Andropogon tectorum New Phytol, 93:591-597

Shoppee, CW (1964). Chemistry of the Steroids, 2nd edn. Butterworths, London.

Stace, CA (1980). Plant Taxonomy and Biosystematics. Edward Arnold Publisher Ltd. London.
Trease, GE; Evans, WCA (1989). Text Book of Pharmacognosy. $3^{\text {rd }}$ eds. Boilliere Tinall Ltd., London.

Wall, ME; Eddy, CR; McClenna, ML; Klump, ME (1952). Detection and estimation of steroids apogeninin plant tissues. Anal Chem. 24, 1337

Wahua, C; Okoli, BE; Sam, SM (2013). The comparative morphological, anatomical, cytological and phytochemical studies on Capsicum frutescens Linn and Capsicum annuum Linn. (Solanaceae). IJSER, 4(1): 1-20. 